\title{
Suicide of the Whaling Industry
}

\author{
Richard Fitter
}

The FPS Honorary Secretary represented both the FPS and the British National Appeal of WWF at the meetings of the International Whaling Commission, in Canberra, Australia, in June 1977. The FPS Statement to the IWC called again for a moratorium on whaling, as proposed at Stockholm in 1972, and commented: 'It is a sobering thought to consider how much larger the whale stocks and quotas were in $\mathbf{1 9 7 2}$ than they are today'.

If you take the events of the 29th annual meeting of the International Whaling Commission at their face value the Commission scored quite a success. All the recommendations of its Scientific Committee were accepted, and where the Committee offered more than one option, the Commission chose the more conservative. In the event quotas were agreed for 9500 fewer great whales than in 1976, and the North Pacific sperm whale fishery is virtually wiped out.* However, even though a few quotas were increased, as with some of the southern sperm whales, the general picture is of a steady decrease of both stocks and quotas, year by year, and it is this which makes one hesitate to take the results of the Canberra meeting at face value. For the plain fact is that the scientists do not know how many whales there are, especially taking them, as they do, stock by stock. The data for the Scientific Committee's prolonged deliberations are wholly inadequate as the basis of a whale management policy. If the Committee were not intellectually committed by its decades of deliberations, it would realise that the fact that stocks go on going down means that its whole approach has been wrong. Its scientific techniques may have been impeccable in the past, though today they are becoming somewhat out of date, but no scientific technique can succeed if the data is inadequate.

With each successive meeting of the IWC the case for the moratorium becomes stronger. Within five years, perhaps less, the moratorium will almost certainly have imposed itself, as each stock now being harvested has to be classified as a protection stock. How much better to bring it in now, when the stocks are still large enough to provide a good basis for recovery, instead of coasting downhill until events force the end of the whaling industry. If ever an industry committed suicide it is the whaling industry. And if further proof were required of Colin Clark's thesis that a profit-making industry will always exterminate its natural resource base, here it is.

Two salient points emerge from the 1977 meeting. One is the predicament of Japan, forerunner of the rest of the overdeveloped world, the other is the increasing unreality of a whale management policy based on inadequate data. Japan is being forced, first of the industrial nations, to face up to the consequences of the Colin Clark syndrome - the fact that once the discount rate on invested capital rises above the rate of renewal of the resource, it pays the entrepreneur to work towards the extermination of the species he is exploiting. For many years the whaling nations, headed by Japan and Russia, have been working towards the extermination of the great whales, only slightly hindered by the policy laid down by the IWC. Commercial extinction

\footnotetext{
* This decision was reversed at the special meeting of the IWC at Tokyo in December.
} 
has been achieved for one stock after another, as the IWC's inadequate conservation measures limped after the commercial drive towards maximisation of profit. Clearly, maximisation of profit, the prime motive of free enterprise economics, just cannot coexist with the exploitation of a natural population, any more than a fox can coexist with a hen-house.

The unreality of the IWC's whale-management policy, based as it has been for some years past on the concept of maximum sustained yield, has become increasingly apparent as at each successive meeting additional whale stocks have had to be protected by being withdrawn from exploitation. Yet the Colin Clark syndrome has driven the Commission on each year to approve quotas that next year proved to be too high. In 1977 the syndrome began to reach its climax, for we are within sight of the extinction of another major whale fishery, that for the North Pacific sperm whales. A few hundred females and a zero quota for males are all that have been approved for the next whaling season. After the Special Meeting of the Scientific Committee, in November 1977, it could be that the whole fishery will have to be suspended, as it was for blue and fin whales in the Antarctic. The impact of this on Japan can be imagined. In terms of invested capital suddenly rendered useless, it is catastrophic. But the catastrophe could easily have been foreseen. Why did Japan make an investment that was almost bound to be rendered useless by the impact of economic upon natural biological forces?

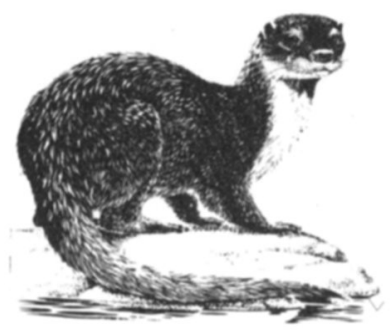

\section{Otters in Britain}

1977 might be called the Year of the Otter in Britain, so great was the activity concerned with its conservation. For the otter is now rare or even extinct in much of the Midlands and south-east England. This was shown by the 1969 and 1974 reports of the Mammal Society published in Oryx (May 1969 and June 1974) and confirmed by the recently published report, Otters $1977^{*}$, of the Joint Otter Group set up in 1976 by the Nature Conservancy Council and the Society for Promotion of Nature Conservation. The otter's status in England and Wales 'gives cause for great concern', says the Report. Unfortunately it goes on to recommend that the otter should not be added to Schedule I of the Conservation of Wild Creatures and Wild Plants Act 1975 (which would give it full protection) 'until the results of research and survey produce more information'. Instead it suggests a 'short-term legislative measure', either as an amendment to the 1975 Act, or as a separate Otter Bill. However, the NCC is fortunately less pusillanimous than its committee and recommended to the Minister for the Environment that the otter be added to Schedule I of the 1975 Act. As Oryx goes to press we learn this has been done.

\footnotetext{
* Free from the NCC, 19/20 Belgrave Square, London SW 1
} 